\title{
Genetic transformation with $G O X$ gene from Penicillium funiculosum as a mean for the increase of potato resistance to the extremal temperatures
}

\author{
Grabelnych O.I. ${ }^{1,2 *}$, Gamburg K.Z. ${ }^{1}$, Stepanov A.V. ${ }^{1}$, Korsukova A.V. ${ }^{1}$, \\ Fedotova O.A. ${ }^{1}$, Polyakova E.A. ${ }^{1,2}$, Zabanova N.S. ${ }^{1,2}$, Borovskii G.B. ${ }^{1}$ \\ ${ }^{1}$ Siberian Institute of Plant Physiology and Biochemistry SB RAS, Irkutsk, Russia \\ ${ }^{2}$ Irkutsk State University, Irkutsk, Russia \\ *email: grolga@sifibr.irk.ru
}

It is desirable to increase potato resistance to low positive and subzero temperatures during its cultivation in zones of insecure agriculture. It is known that regulation of plant resistance to adverse environmental factors is connected with short term increase of the concentration of reactive oxygen species (ROS), which are signaling molecules for the induction of protective mechanisms. Introduction and expression of GOX gene (which encodes glucose oxidase enzyme) in plant genome induce constantly higher content of hydrogen peroxide in plant tissues and such plants may be used as a model system for the study of resistance to the extremal temperatures. Potato tubers (cv. Skarb) transformed with GOX from Penicillium funiculosum under the control of 35S RNA CaMV promoter were obtained from the Institute of Genetics and Cytology of NAS of Belarus, Minsk, Belarus. Transgenic plants of potato cultivated in vitro had high glucose oxidase activity and increased content of hydrogen peroxide compared with untransformed plants or plants transformed with the empty vector. Plantlets were treated with cold $\left(1{ }^{\circ} \mathrm{C}\right.$ for $\left.10 \mathrm{~d}\right)$ or heat $\left(50{ }^{\circ} \mathrm{C}\right.$ for $\left.1.5 \mathrm{~h}\right)$ and examined for their resistance. It was established that plantlets transformed with $G O X$ were significantly more resistant to cold treatment. However, transgenic lines were more sensitive to heat. Pretreatment with $37^{\circ} \mathrm{C}$ for $2 \mathrm{~h}$ led to total disappearance of heat sensitivity in untransformed plantlets and only partial restoration in transgenic ones. The possible biochemical mechanisms for increasing cold resistance and decreasing heat resistance of potato plants with the expressed $G O X$ gene are discussed. It is possible to suppose that the practical use of GOX gene is inappropriate. But other promoters which can increase resistance to both stresses will allow using this gene for genetic transformation of agricultural plants. 